\title{
SIMULACRE: A proposal for practical training in e learning environments
}

\author{
Alba Colombo' and Muriel Gómez Pradas² \\ 1. Universitat Oberta de Catalunya (UOC), Spain | acolombo@uoc.edu \\ Submitted in: March 2013 \\ 2. Universitat Oberta de Catalunya (UOC), Spain | mgomezpr@uoc.edu

\section{Recommended citation}

Colombo, A. \& Gómez, M. (2014). SIMULACRE: A proposal for practical training in e learning environments. RUSC. Universities and Knowledge Society Journal, 11(3). pp. 4-21. doi http://dx.doi.org/10.7238/rusc.v11i3.1781

\begin{abstract}
This article describes an educational innovation project called SIMULACRE, funded by the Office of the Vice President for Research and Innovation at the Universitat Oberta de Catalunya (Open University of Catalonia, UOC) through a grant awarded under APLICA 2011. This project focuses on the design, development, implementation and evaluation of a new methodology for practical training in e-learning environments.

The first part of the article gives an introduction to the features of the UOC's educational model and to the various experiences of practical training in e-learning environments within the university. The second part presents a new proposal for practical training called SIMULACRE, which is based on a model that combines the theory of simulation games, problem-solving and cooperative learning. This part specifies the curricular competencies to be developed, the teaching stages into which their development is divided, and the new educational resources that this practical training model requires.

The last part of this article presents the evaluation process done after the first implementation of the model in the practical subject seminars of the UOC master's degree in Cultural Management in 2011. This evaluation had a two-pronged analysis, first of the SIMULACRE objectives, and second of the students' competency acquisition.

The results indicate that SIMULACRE is an educational proposal that allows practical training to be done online and offers the possibility of having direct contact with professionals, of team working and of decision making. They also show that it is a model that enables students to satisfactorily acquire competencies relating to problemsolving, decision-making and critical analysis. The article concludes that SIMULACRE is a valid proposal for gaining access to and doing practical training in e-learning environments.
\end{abstract}

\section{Keywords}

practical training; e-learning; evaluation; competencies; practical training model; educational innovation 


\section{SIMULACRE: Una propuesta de prácticas en entornos e-learning}

\section{Resumen}

En el presente artículo se describe el proyecto de innovación docente SIMULACRE, financiado por el Vicerrectorado de Investigación e Innovación de la Universitat Oberta de Catalunya (UOC) en la convocatoria anual APLICA 2011. Dicho proyecto se centra en el diseño, el desarrollo, la implementación y la evaluación de una nueva metodología de aprendizaje práctico en entornos virtuales o de e-learning.

En la primera parte del artículo se introducen las particularidades del modelo educativo así como las distintas experiencias de prácticas en entornos e-learning existentes en la UOC. En la segunda parte del artículo se expone una nueva propuesta de prácticas Ilamada SIMULACRE, modelo que combina la teoría de los juegos de simulación, el problem solving y el aprendizaje cooperativo. Se explicitan las competencias curriculares que van a desarrollarse, las fases de docencia en las que se ha dividido su desarrollo y los nuevos materiales para este modelo de prácticas.

En la última parte de este artículo se expone el proceso evaluativo que tuvo lugar después de la primera implementación del modelo en las aulas de la asignatura de prácticas del máster universitario de Gestión cultural. Para dicha evaluación se planteó un análisis en función de los objetivos de SIMULACRE, así como en base a la evaluación competencial de los alumnos.

LOS resultados indican que SIMULACRE es una propuesta docente que permite desarrollar prácticas de forma no presencial, ofrece la posibilidad de tener contacto directo con los profesionales, así como de trabajar en equipo y ejercer la toma de decisiones. También se ha demostrado que es un modelo que permite a los estudiantes adquirir satisfactoriamente competencias relacionadas con la resolución de problemas, la toma de decisiones y el análisis crítico. El artículo llega a la conclusión de que SIMULACRE es una propuesta válida para acceder a desarrollar prácticas en entornos virtuales.

\section{Palabras clave}

prácticas; e-learning; evaluación; competencias; modelo de aprendizaje de prácticas; innovación docente 


\section{Introduction. The UOC and existing models for practical training in e-learning environments}

The educational innovation project called SIMULACRE'1 proposes a new model for postgraduate-course practical training in e-learning environments. The idea for the project arose from the inherent difficulty of doing practical subjects in an e-learning environment. It is a particularly significant problem on master's degree courses with a professionally oriented profile, as is the case of the university master's degree in Cultural Management offered jointly by the Universitat Oberta de Catalunya (Open University of Catalonia, UOC), the University of Girona (UdG) and the University of the Balearic Islands (UIB).

The UOC educational model (Guitert, 2005; Santacana, 2006) is implemented through the use of information and communication technologies (ICTs). It is an educational model based on asynchronicity, meaning that the students and the lecturer do not share the physical or temporal space of a conventional classroom. In this educational model, the student is the central figure (Duart \& Sangrà,2000) and the lecturer is the person who accompanies him or her in the learning process. Therefore, unlike what happens in face-to-face universities, the lecturer is not a beacon of knowledge.

It is also important to bear in mind that UOC students have a specific profile (Carnoy, 2012), which substantially distinguishes them from face-to-face university students. As a general rule, they are over 30 years old and working, and have prior university qualifications and family responsibilities. For many UOC students, it has been found that one of the main reasons for enrolling again at a university is for career and/or personal advancement. Consequently, they place high demands not only on the quality of the studies they take, but also on themselves.

Given the characteristics of the UOC educational model, the practical application of certain learning content, such as professionally oriented practical training, can be complex.

In the university context, several studies have been conducted on the integration of practical training into the university curriculum in order to attain a suitable professional profile (Molina, 2008; Zabalza, 2011). As Dr Molina (2008) has pointed out, this has been an issue of particular relevance since the Bologna Plan. Indeed, the Plan confers a prominent role on practical training because it is understood to facilitate a constant recreation of theory and practice, and the development of research-action processes, all of which are considered the basic pillars supporting the acquisition of quality professional competencies (Molina, 2008: 337).

However, very few of the studies conducted thus far have taken into account the incorporation of ICTs into the learning process, and even fewer touch on the specific problems encountered by universities offering a fully online education.

Despite the complexity of doing practical subjects in an e-learning environment, the UOC has tried to solve this problem by means of several different models. On the various programmes run by the Arts and Humanities Department, ${ }^{2}$ two types of practical training have been offered: face-to-face and institutional.

The first type is face-to-face practical training understood in the traditional sense, where a student is physically present for a specific period of time in an institution, firm or organisation. Before a student does the practical training, the lecturer and the institution agree on the tasks that the student will perform in order to ensure that he or she is able to apply the knowledge that he or she has acquired throughout the course. In addition, the student is

\footnotetext{
1. Project funded by the Office of the Vice President for Research and Innovation at the Universitat Oberta de Catalunya (Open University of Catalonia, UOC) through a grant awarded under APLICA 2011. Project code: IN-1109 PID.

2. Both the former long degree in Humanities and the current bachelor's degree in Humanities.
} 
tutored by a professional working for the institution where he or she does his or her practical training, the purpose of which is to provide real monitoring of the learning process.

The second type, which we have termed 'institutional', is done virtually in collaboration with institutions. It consists of the tutorship of a student's work by an institution. The institution and the lecturer in charge of the subject agree on the practical training, and there is direct virtual communication among the tutor designated by the institution, the student and the lecturer.

Besides the above, some of the UOC's technology-related master's degrees contemplate virtual practical training only, with the creation of virtual laboratories ${ }^{3}$ in which group exercises using the latest versions of the most commonly used software in these academic programmes are performed. In other cases, the students are given a choice of two options: to do face-to- face practical training or institutional practical training ${ }^{4}$.

However, the problem with this type of practical training, even when in theory it is virtual (as is the case for institutional practical training), resides in the fact it often proposes or requires a level of physical presence that students with the UOC profile find difficult to comply with, given that the university's educational model is based on asynchronicity. Faced with this complex situation, and after analysing the various experiences of practical training that the UOC offers, some positive aspects were identified, as were others that could be improved. Focusing on those aspects that could be improved, we would summarise them as: (1) the fundamentally theoretical nature of this type of practical training, (2) the scant relationship between the students and the professionals at the institutions in which the practical training is done (3) the remoteness of the practical training that the students do from the most relevant aspects of an institution's day-to-day work.

Consequently, on the joint UOC-UdG-UIB university master's degree in Cultural Management, the need for a new type of practical training in an e-learning environment was considered in order to take advantage not only of the new scenarios that an online university offers, but also of the opportunities that new technological tools afford for learning. Also taken into account was the fact that, in an e-learning environment, it is all the more important to find new forms of interaction capable of solving those aspects in need of improvement that we had identified, and to opt for innovative and completely virtual systems of practical training that the students would find as interesting as, or even more interesting than face-to-face practical training.

The SIMULACRE project was therefore designed to enhance the methodological and conceptual approaches to the practical subject on the university master's degree in Cultural Management by using an innovative format, the main objective of which was to bring students closer to the practical reality of working professionals, yet in a virtual, asynchronous way.

\section{SIMULACRE, an innovative proposal}

The design of the SIMULACRE project is based on a new educational proposal for students' practical training in virtual environments. In this model, learning is centred on simulation ${ }^{5}$, which is understood as mirroring

\footnotetext{
3. The university master's degree in Telecommunications Engineering and the university master's degree in Computer Engineering. 4. For example, the master's degree in Conflictology and the university master's degree in Telemedicine.

5. In some Law and Political Science subjects at the UOC, simulation games are also used. In these cases, they are not practical training subjects, and the simulation does not form an integral, crucial part of the educational design and structure of the subject. Rather, it is yet another educational methodology that is used in the design of the Continuous Assessment Tests (CATs).
} 
reality through a real simulation exercise in which students must address an issue by working cooperatively. The model therefore combines several methodologies, including simulation games (Martín, 1985; Fraile, 1995; López \& Martínez, 2001), problem-solving (Escribano \& Valle, 2010; Ferreira de Araújo \& Sastre, 2008) and cooperative learning (Monereo \& Duran, 2003; Pujolàs, 2007).

We understand simulation as a strategy that brings students closer to a situation akin to a real-life one. This enables them to get an insight into the tasks and issues of the day-to-day management of cultural institutions, firms or organisations. The information that students receive is factual. In other words, they obtain data that enable them to get an insight into an institution's situation and perform an in-depth analysis of it (Martín, 1985; Fraile, 1995; López \& Martínez, 2001). Based on that factual information, the simulation creates an environment that is as similar to the real one as possible, from which issues arise that the students will need to address.

Problem-solving is understood as part of the educational design, and it enables students to learn by posing a problem or raising an issue that needs to be addressed (Escribano \& Valle, 2010; Ferreira de Araújo \& Sastre, 2008). According to Nardone (2010), problem-solving is a method for finding solutions to a problem from the various stages that the processes of scientific research follow. In this respect, the SIMULACRE model is based on a situation analysis of a particular case; it proposes an issue to be addressed, analyses the various solutions, identifies a final proposed solution, and compares the one put forward by the students and the one that the institution eventually decided to implement.

Finally, cooperative learning (Monereo \& Duran, 2003; Pujolàs, 2007) is an integral part of SIMULACRE's educational design, that is to say, of the educational model proposed by this project. This takes the form of work done among students on the one hand, and of interaction among students, lecturers and working professionals on the other. In this respect, we understand cooperative learning as collaboration among students through their interaction via the online platform of the UOC's virtual learning environment (VLE).

SIMULACRE proposes a triangulation of these three learning techniques: the simulation of a real situation combined with problem-solving teaching through cooperative learning among students and their interaction with lecturers and working professionals.

Therefore, the proposal made by this new educational model for practical training in e-learning environments focuses on the analysis of a particular case, thus raising a factual issue in a real institution that the students will need to address. For the first edition of this application, three cases from real cultural institutions were chosen in accordance with the specialisations of the master's degree; the Picasso Museum in Barcelona for heritage students, the Tàrrega Street Theatre Fair for cultural industries students, and Icono Serveis Culturals, a firm offering cultural visits and tourist tours around Barcelona and Catalonia, ${ }^{6}$ for cultural tourism students.

Through the SIMULACRE proposal, students get real experience of decision-making as they reason and work cooperatively to address an issue arising from a situation in which the aforementioned institutions find themselves. Following the parameters of the theoretical foundation of the methodology employed, in this case problemsolving, the students compare and contrast various views and then opt for a single proposed solution after taking into account the strengths, weaknesses, opportunities and threats. Finally, in order to complete the approach to the practical training simulation in this real case, the students talk to the professional and compare the proposed solution that they have developed with the one that the expert actually implemented, thus getting the opportunity

6. We would like to thank all of the institutions for their full collaboration, and the professionals who took an active part in the whole process. 
to compare and examine specific aspects of the solutions, and to learn about the know-how that the expert contributes.

Therefore, we understand that the training model proposed by SIMULACRE provides added value when it come to providing students with an insight into issues arising from situations, which would be difficult for them to get in face-to-face practical training.

\subsection{The SIMULACRE model}

The SIMULACRE model was designed to work on and evaluate a number of the students' curricular competencies, including: the ability to apply models, tools and procedures to the professional environment of cultural management; the ability to critically analyse solutions to real issues and problems in the field of cultural management; the ability to perform decision-making and strategic-planning tasks in the professional environment of cultural management; the ability to analyse when performing problem-solving tasks; and the ability to manage and work consistently in a collaborative environment.

In order to work on these curricular competencies, five different action areas were defined for the learning process as a whole: (1) describing and contextualising exemplary cultural institutions, firms and organisations, (2) introducing the student to an issue arising from a complex management situation in need of a solution, (3) the student's involvement in the research and design of the solution or strategy improvement of the institution in order to address the issue raised or situation presenting itself, (4) the students' reasoned selection of the best proposed solution to address the issue, (5) and comparing the solution put forward by the students with the solution implemented by the professionals.

These areas are articulated around three key educational stages: designing a structure to organise a student's pace of learning at the different times when the aforementioned theoretical foundations are applied, and designing specific resources to guide the simulation of a factual issue case within a real cultural institution.

The first stage centres on the introduction to the institution in which the students are going to do their practical training in an e-learning environment. At this stage, the students will study the strengths, weaknesses, opportunities and threats of the case they are addressing, getting to grips with a real situation in a simulated manner (Martín, 1985; Fraile, 1995; López \& Martínez, 2001). The resources that the students have available to them in the seminar, together with data that they can obtain from their own research, are the bases on which discussion about the institution's operations and current situation can be developed.

The second stage is designed to present and get the students to address the issue, that is to say, to expound, analyse and solve the problem that the institution is facing. At this stage of the learning process, the students have to address the issue and find potential ways of solving it by working cooperatively or, that is, learning by cooperating (Monereo \& Duran, 2003; Pujolàs, 2007). In order to undertake this activity, the students - once again following the rules of simulation games - take on roles as employees of the institution, divided into the departments that exist within it. The students will discuss and agree on these proposals in order to arrive at a final proposed solution, working at all times on problem-solving (Escribano \& Valle, 2010; Ferreira de Araújo \& Sastre, 2008). Guided by the subject lecturers, this process should enable the students to compare their decisions and approaches.

At the third and final stage, the students will be able to see the final solution that was actually implemented by the institution analysed. At this stage, the students receive supplementary resources detailing the action plan that the institution implemented. At this moment in the learning process, the students must perform a comparative 
analysis of the proposed solutions. In order to do that, they are able to have direct contact with a working professional from the institution, with whom they can discuss any aspects, questions and topics that may have arisen during the decision-making process.

On the basis of the stages already described, and in order to further develop this learning process, several videos were designed as practical training resources. These videos allowed the students to get closer to the institution, to the people working in it, and to the situation in which it found itself. The specific nature of these resources, and what makes them unique to this model, is that they were designed and made in accordance with the various stages of the training model that SIMULACRE proposes. In other words, a range of videos was made, from reports to fictional video clips, that enabled the students to get an insight into the cases, their issues and their problems, so that they could get directly involved - in a simulated manner and through cooperative learning - in solving the problems of real institutions. As already mentioned, the institutions with which we collaborated in order to implement the first edition of this model were the Picasso Museum of Barcelona, the Tàrrega Street Theatre Fair and Icono Serveis Culturals.

The lecturers on the innovation project team and the managers of the aforementioned cultural institutions designed the audiovisual resources of the three stages of the learning process for each of the institutions, that is to say, the introduction, the issue and the solution. During the resource design process, it was considered crucial that the reference person in the analysed institution should be both the lead in the videos and the guest taking part in the seminar in the last stage of the learning process.

Thus, SIMULACRE proposes a model for practical training in e-learning environments that is specific and unique, as it combines the aforementioned methodological foundations and their application to real cases presented in the seminars by means of videos specifically designed for these courses. It therefore brings students closer to real situations, establishing direct contact with the institutions' working professionals.

\section{Evaluation of the experience}

In the first edition of the SIMULACRE model application, there were a total of 137 students enrolled on the practical training subject ${ }^{7}$. These were allocated to three virtual seminars in accordance with the specialisations that they were taking and also the institutions in which they would do their practical training by means of this new model.

The results of this innovation project were evaluated on the basis of the learning process ratings given by the students and the teaching team alike. On completion of the teaching, a process was initiated to evaluate the model. This combined two elements: an evaluation based on the objectives of the model, and an evaluation based on the competencies acquired by the students.

In order to carry out this evaluation, a student survey was done. The grades obtained by the students in each of the competencies were also taken into account. An analysis of these data is thus proposed, using the various indicators and evaluation instruments shown in the following table.

7. It is important to specify that this is the total number of students enrolled on the professional specialisation of the master's degree, since the practical training subject is a compulsory part of that specialisation. 
Table 1. Indicators and evaluation instruments

\begin{tabular}{|c|c|c|c|}
\hline Objectives, competencies and results & Indicator & Indicator type & $\begin{array}{l}\text { Evaluation } \\
\text { instrument }\end{array}$ \\
\hline \multicolumn{4}{|c|}{ 1. Evaluation based on the objectives of the model } \\
\hline To foster the students' practical work. & $\begin{array}{l}\text { Percentage of students stating that the practical } \\
\text { topics worked on during the subject were } \\
\text { relevant to the content of the master's degree. }\end{array}$ & Quantitative & Student survey \\
\hline $\begin{array}{l}\text { To create interaction between the students and } \\
\text { the institutions' professionals. }\end{array}$ & $\begin{array}{l}\text { Percentage of students stating that interaction } \\
\text { with the professionals was interesting or very } \\
\text { interesting. }\end{array}$ & Quantitative & Student survey \\
\hline $\begin{array}{l}\text { To situate the students in a real decision-making } \\
\text { context and to foster teamwork in order to } \\
\text { manage situations of change. }\end{array}$ & $\begin{array}{l}\text { Percentage of students stating that they had } \\
\text { been able to team work and perform decision- } \\
\text { making tasks. }\end{array}$ & Quantitative & Student survey \\
\hline $\begin{array}{l}\text { To increase the students' level of knowledge } \\
\text { about the institutions. }\end{array}$ & $\begin{array}{l}\text { Percentage of students stating that the level of } \\
\text { knowledge that they had acquired about the } \\
\text { institutions with which they had worked was } \\
\text { high or very high. }\end{array}$ & Quantitative & Student survey \\
\hline \multicolumn{4}{|c|}{ 2. Evaluation based on the competencies acquired by the students } \\
\hline Ability to apply procedural methods and tools. & $\begin{array}{l}\text { Percentage of students who got a grade B or } \\
\text { higher for this competency. }\end{array}$ & Quantitative & $\begin{array}{l}\text { Evaluation and } \\
\text { students' grades }\end{array}$ \\
\hline $\begin{array}{l}\text { Ability to critically analyse an issue arising from } \\
\text { a situation. }\end{array}$ & $\begin{array}{l}\text { Percentage of students who got a grade B or } \\
\text { higher for this competency. }\end{array}$ & Quantitative & $\begin{array}{l}\text { Evaluation and } \\
\text { students' grades }\end{array}$ \\
\hline $\begin{array}{l}\text { Ability to perform decision-making and strategic- } \\
\text { planning tasks. }\end{array}$ & $\begin{array}{l}\text { Percentage of students who got a grade B or } \\
\text { higher for this competency. }\end{array}$ & Quantitative & $\begin{array}{l}\text { Evaluation and } \\
\text { students' grades }\end{array}$ \\
\hline $\begin{array}{l}\text { Ability to analyse when performing problem- } \\
\text { solving tasks. }\end{array}$ & $\begin{array}{l}\text { Percentage of students who got a grade B or } \\
\text { higher for this competency. }\end{array}$ & Quantitative & $\begin{array}{l}\text { Evaluation and } \\
\text { students' grades }\end{array}$ \\
\hline Ability to manage consistently and sustainably. & $\begin{array}{l}\text { Percentage of students who got a grade B or } \\
\text { higher for this competency. }\end{array}$ & Quantitative & $\begin{array}{l}\text { Evaluation and } \\
\text { students' grades }\end{array}$ \\
\hline
\end{tabular}

Source: Own elaboration

\subsection{Evaluation based on the objectives of the model}

On completion of the teaching, a survey was conducted on the 137 students enrolled on the practical training subject, in which the new model had been implemented. A total of 80 exploitable responses were obtained, representing 58.3\% of the total number of students on the practical training subject in the respective semester.

We shall now go on to look at and analyse the data obtained for each objective of the SIMULACRE model.

As shown in Table 1, the first objective was to foster the students' practical work, and the analysis indicator was the percentage of students stating that the practical topics worked on during the subject were relevant to the content of the master's degree. 
Chart 1. Opinions about fostering the students' practical work

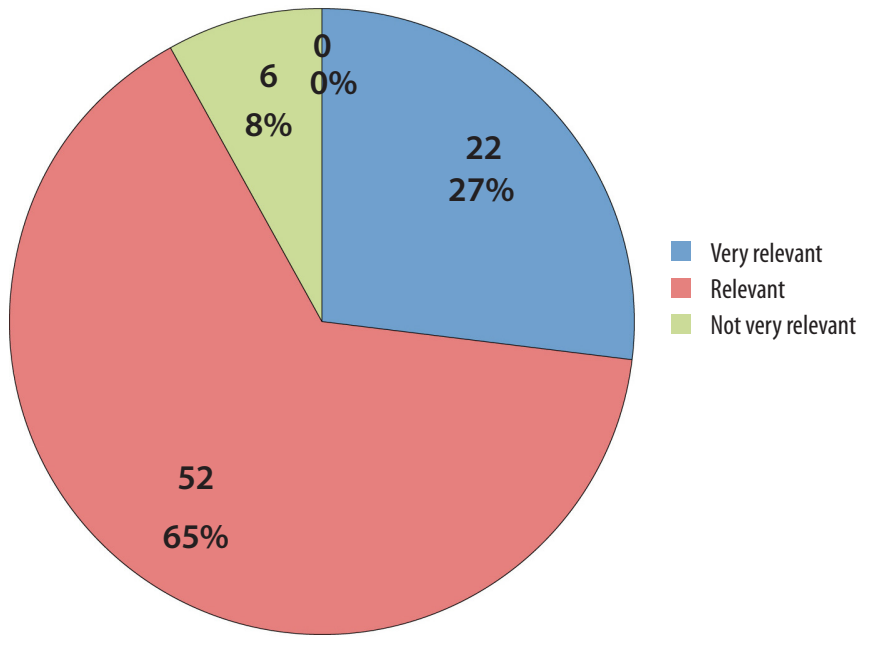

Source: Own elaboration based on data obtained from the survey

In this chart, it is surprising to find that $92 \%$ of the survey respondents considered that the practical topics covered during the subject were relevant (65\%) and very relevant (27\%) to the content of the master's degree.

The second objective (see Table 1) was to create interaction between the students and the institutions' professionals.

Chart 2. Level of satisfaction in relation to interaction with the professionals

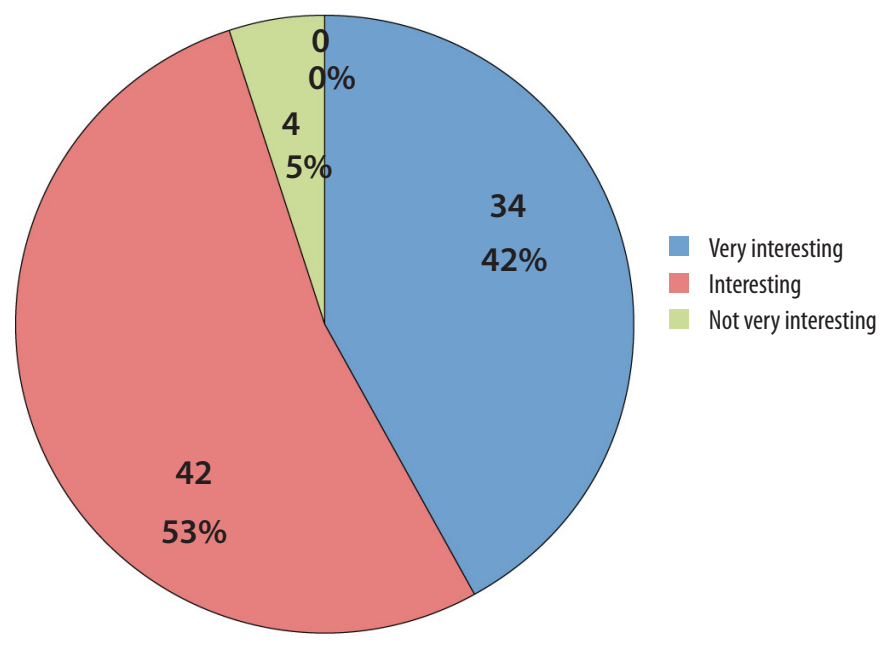

Source: Own elaboration based on data obtained from the survey 
This chart shows that $95 \%$ of the survey respondents considered that the interaction between them and the working professionals was interesting (53\%) and very interesting (42\%).

The third objective (see Table 1) was to situate the students in a real decision-making context and to foster teamwork in order to manage situations of change.

\section{Chart 3. Opinions about decision-making and teamwork}

Teamwork
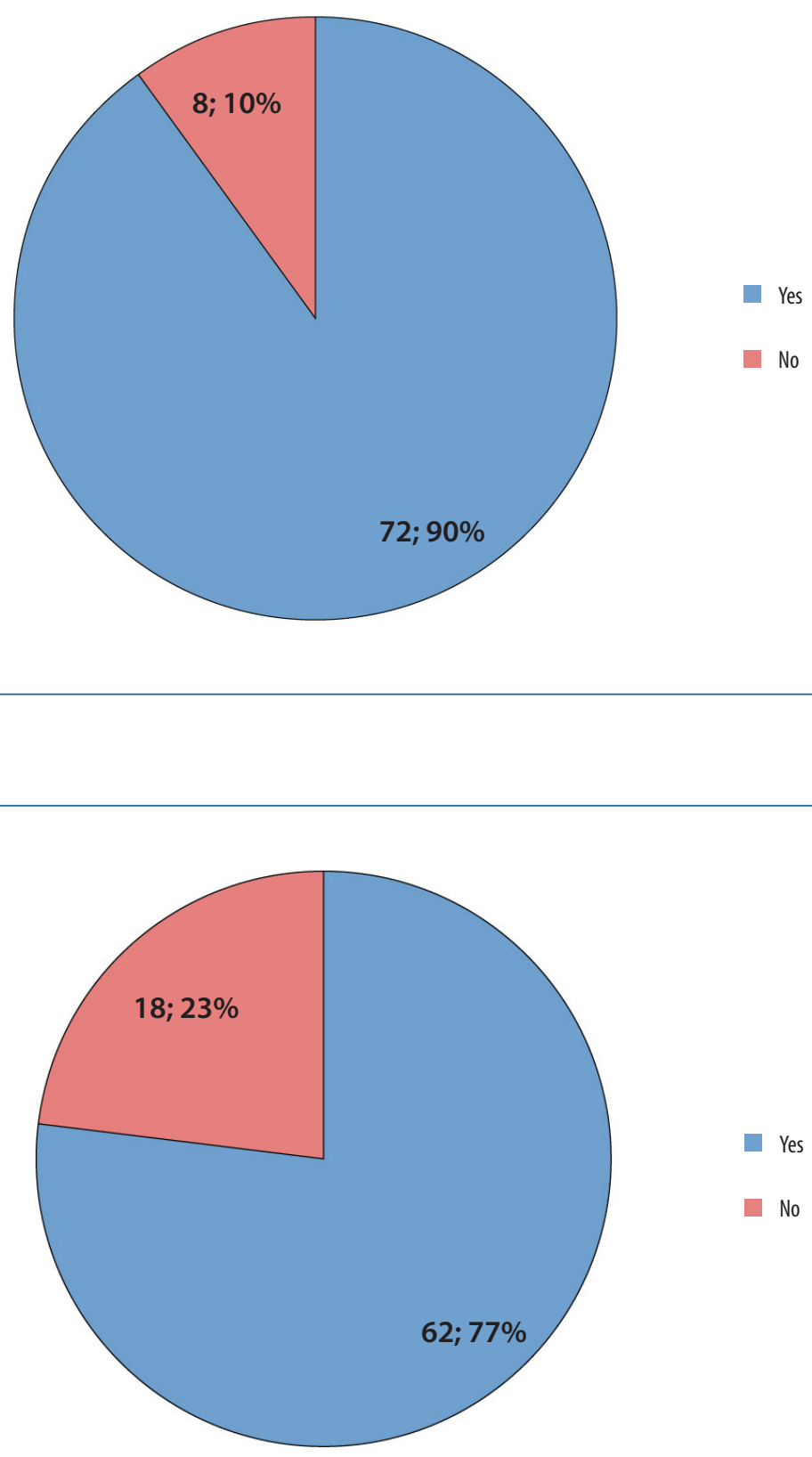

Source: Own elaboration based on data obtained from the survey 
According to these charts, $90 \%$ of the survey respondents considered that this training model offered them the opportunity to team work. Moreover, $77 \%$ of the survey respondents felt that this methodology enabled them to make decisions.

The fourth objective (see Table 1) was to increase the students' level of knowledge about the institutions.

Chart 4. Opinions about the level of knowledge acquired about the institutions

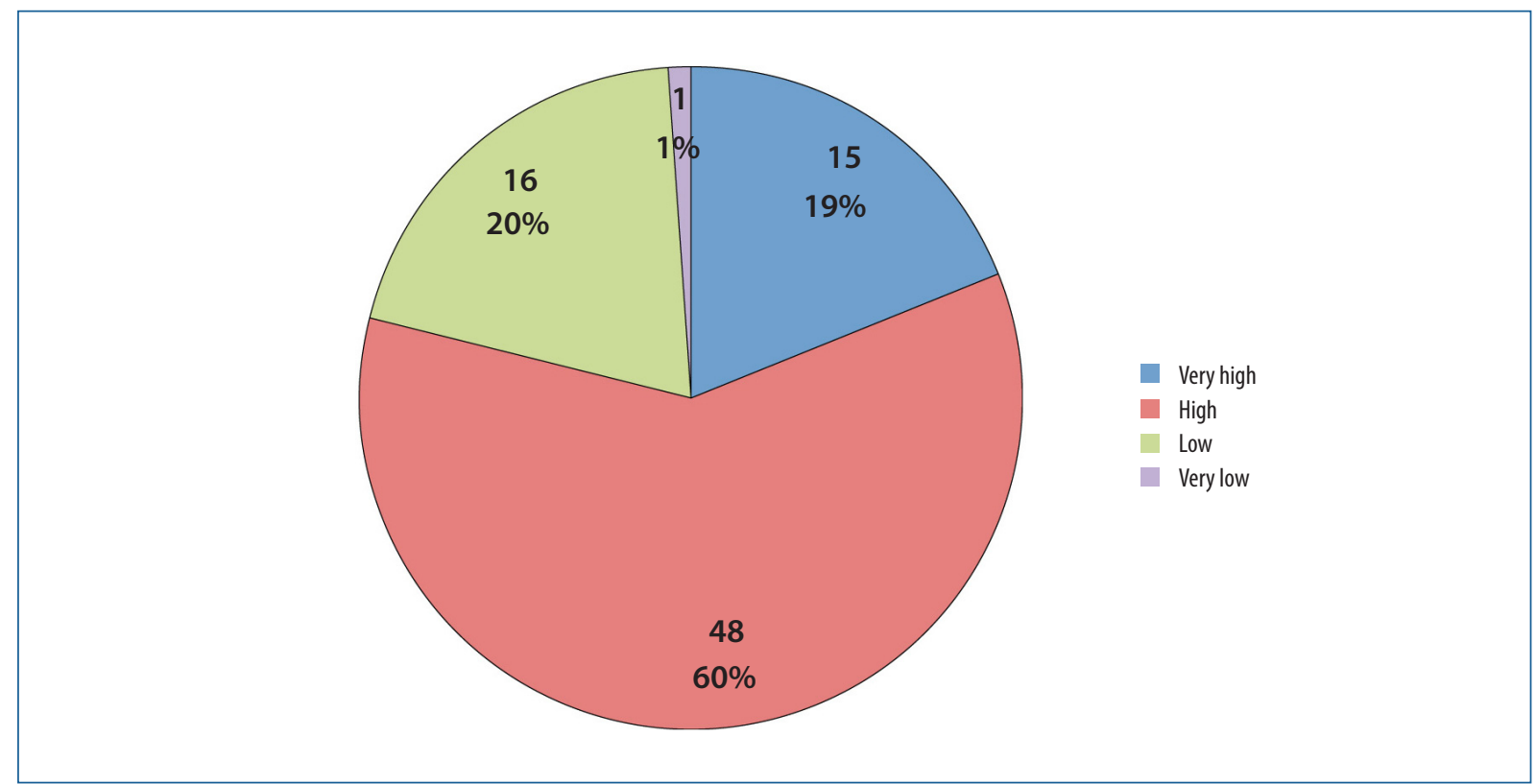

Source: Own elaboration based on data obtained from the survey

This chart shows that $79 \%$ of the survey respondents considered the level of knowledge about the cultural institutions in which they had done their practical training was high (60\%) and very high (19\%).

Therefore, from the data presented thus far, it can be deduced that the SIMULACRE model fostered practical work among the students, offered the students the opportunity to interact with working professionals, offered them the opportunity to team work and perform decision-making tasks, and provided them with a better knowledge of the institutions in which they did their practical training.

\subsection{Evaluation based on the competencies acquired by the students}

The evaluation based on the competencies acquired by the students enabled us to identify whether the proposed training model was suitable for developing competencies of this type among students.

This evaluation was computed by taking the grades obtained by the students in each of the competencies proposed in this subject. As shown in Table 1, the indicator that enabled us to establish whether or not the students had acquired the competency was the percentage of students that had managed to get a grade B or higher in it ${ }^{8}$.

8. The UOC educational model contemplates alphabetical and numerical grades. The different grades that a student can get are: A (excellent, 10-9), B (good, 8-7), C+ (pass, 6-5), C- (fail, 4-3), D (fail, 2-1) and N (no show). 


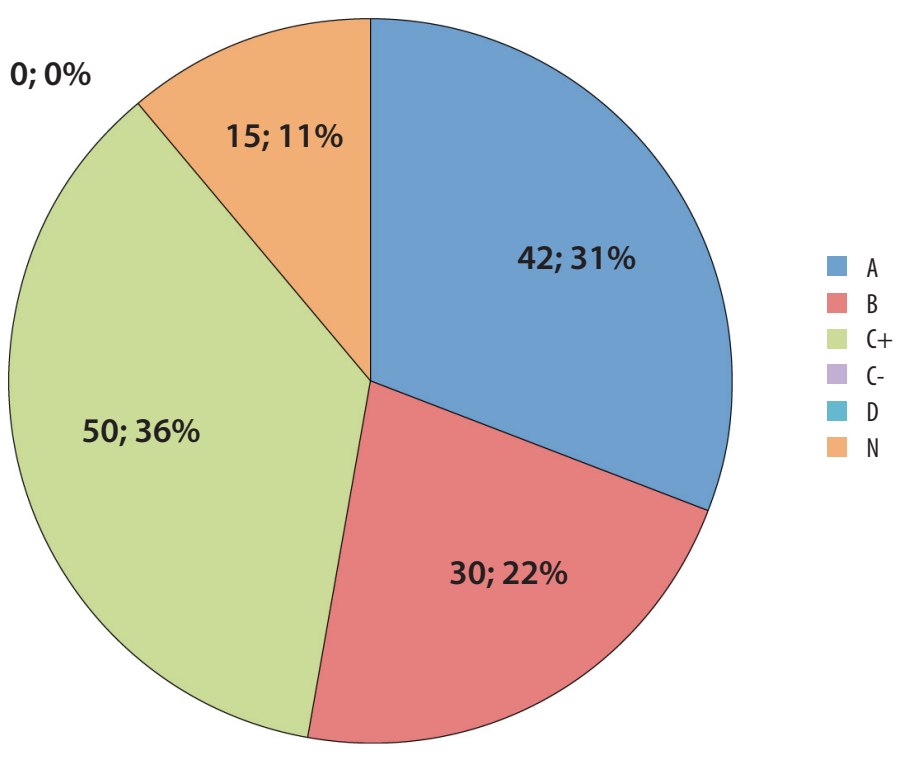

Ability to critically analyse an issue arising from a situation

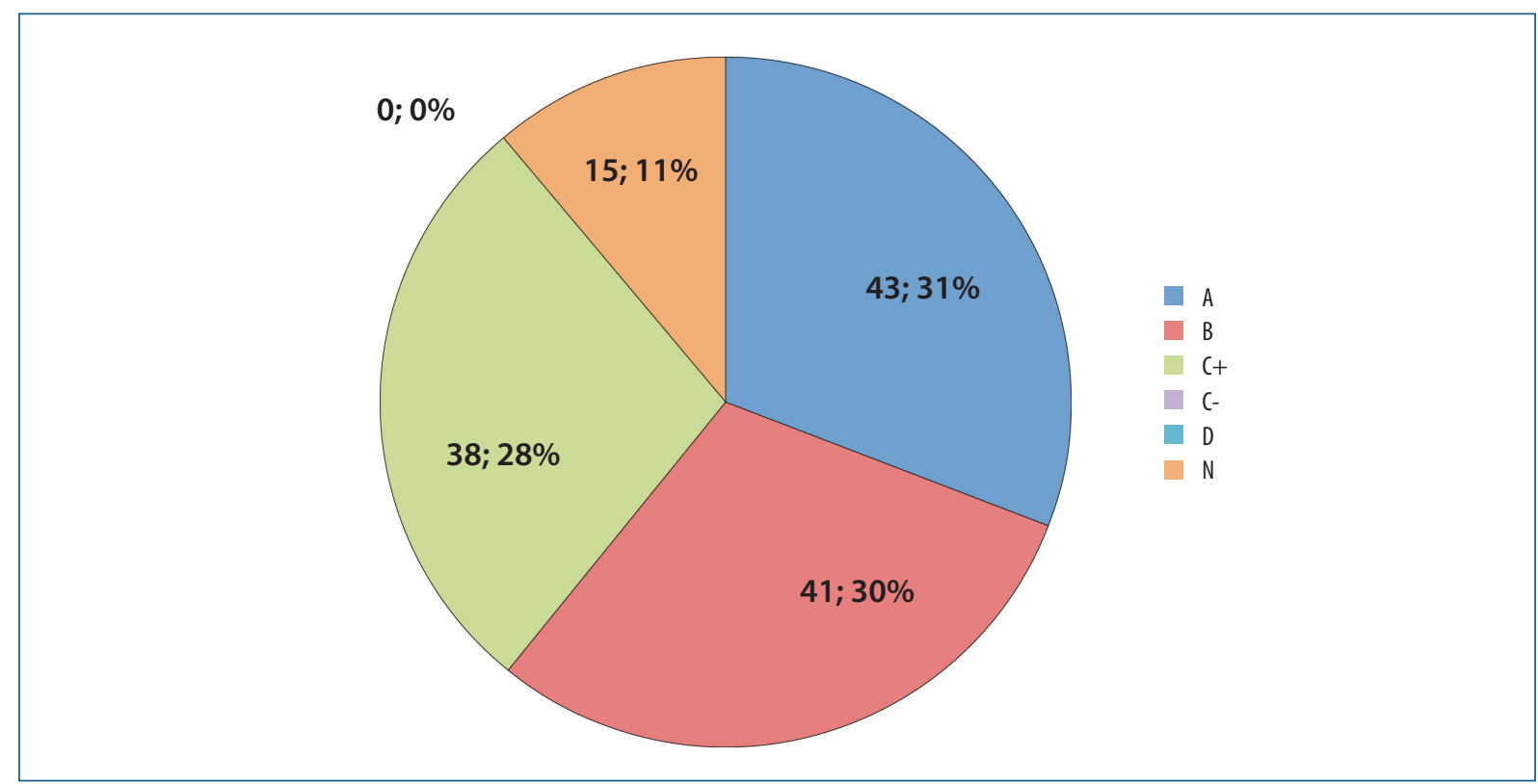

According to these data, the majority of the students got good grades ( $B$ or $A$ ) in nearly all of the competencies. For example, for the competency relating to the ability to apply methods and tools, 53\% of the students got good grades (B or higher). For the competency relating to the ability to critically analyse an issue arising from a situation, $61 \%$ of the students got good grades (B or higher). For the competencies relating to decision-making and problemsolving, $63 \%$ and $65 \%$ of the students got good grades, respectively. For the ability to manage consistently and sustainably, $52 \%$ of the students got good grades. 


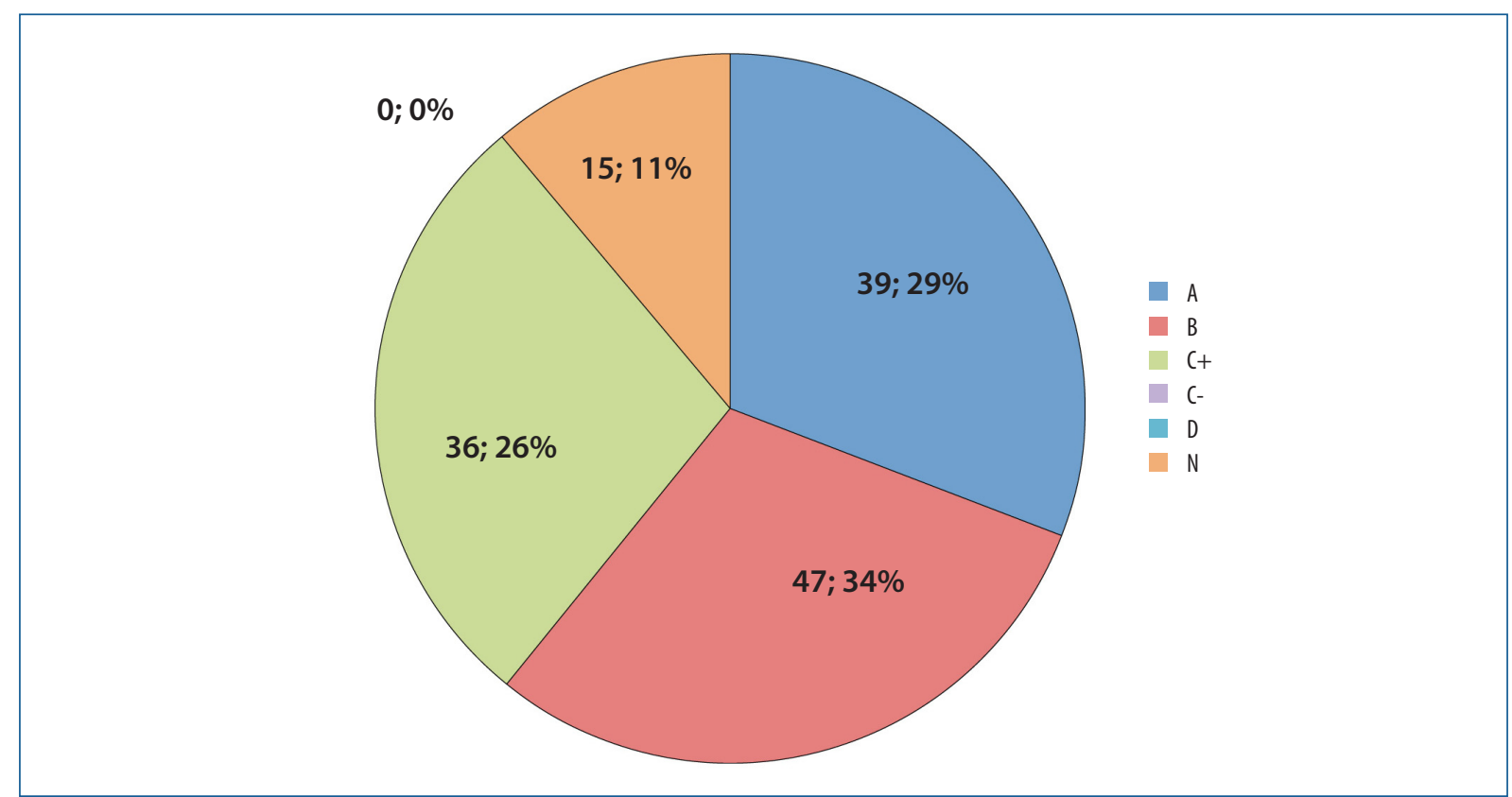

Ability to analyse when performing problem-solving tasks

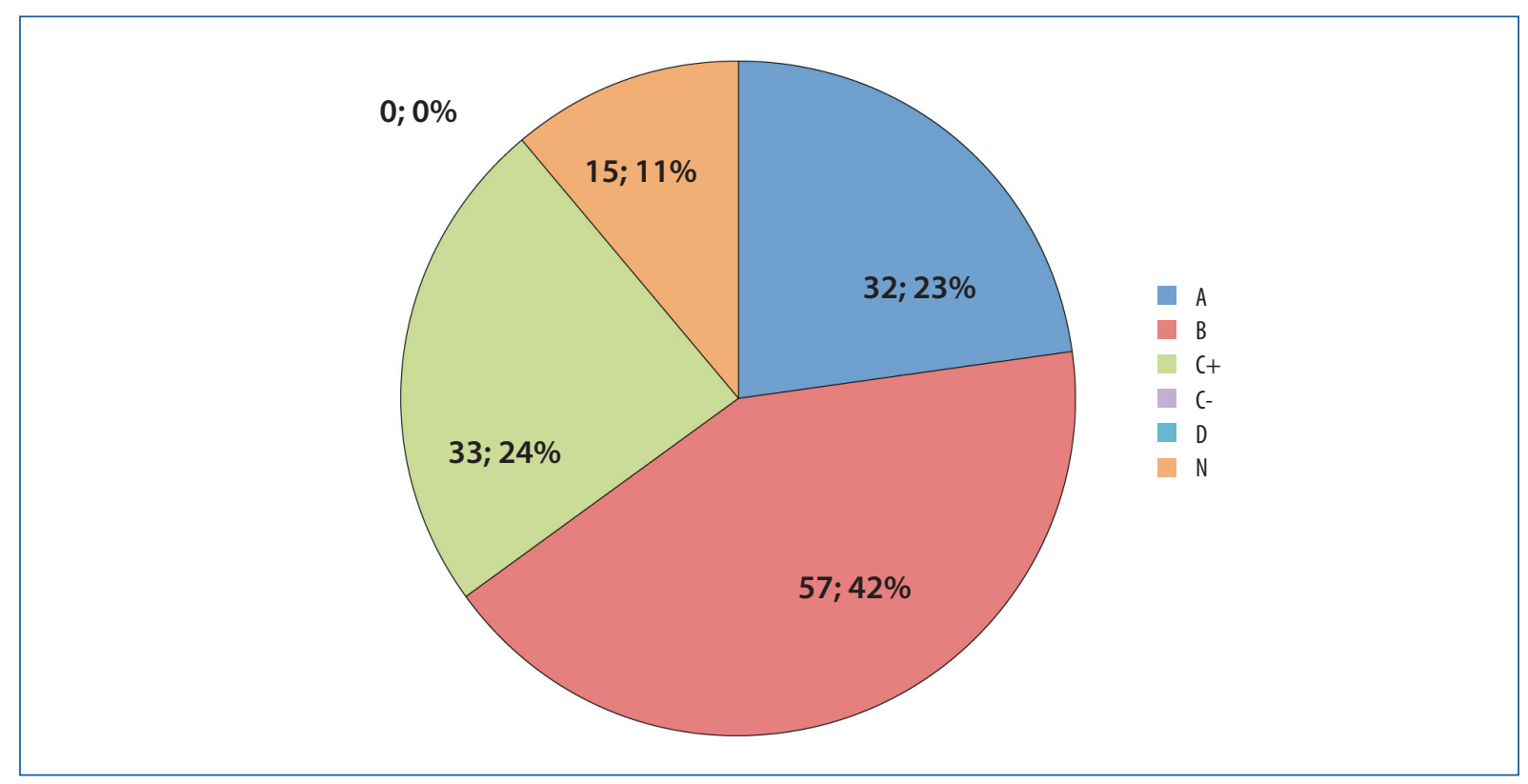

These data show that the students acquired some competencies better than others. For example, for those relating to critical analysis, decision-making and problem-solving, a higher percentage of the students got good grades. In contrast, for those relating to the application of methods and the ability to manage consistently and sustainably, a lower percentage of the students got good grades.

Moreover, if we take a look at the students' grades shown in Chart 6 , we can see that the majority of the students got a $\mathrm{C}+$ grade in some competencies. This is the case for the competency relating to the application of methods 
Ability to manage consistently and sustainably

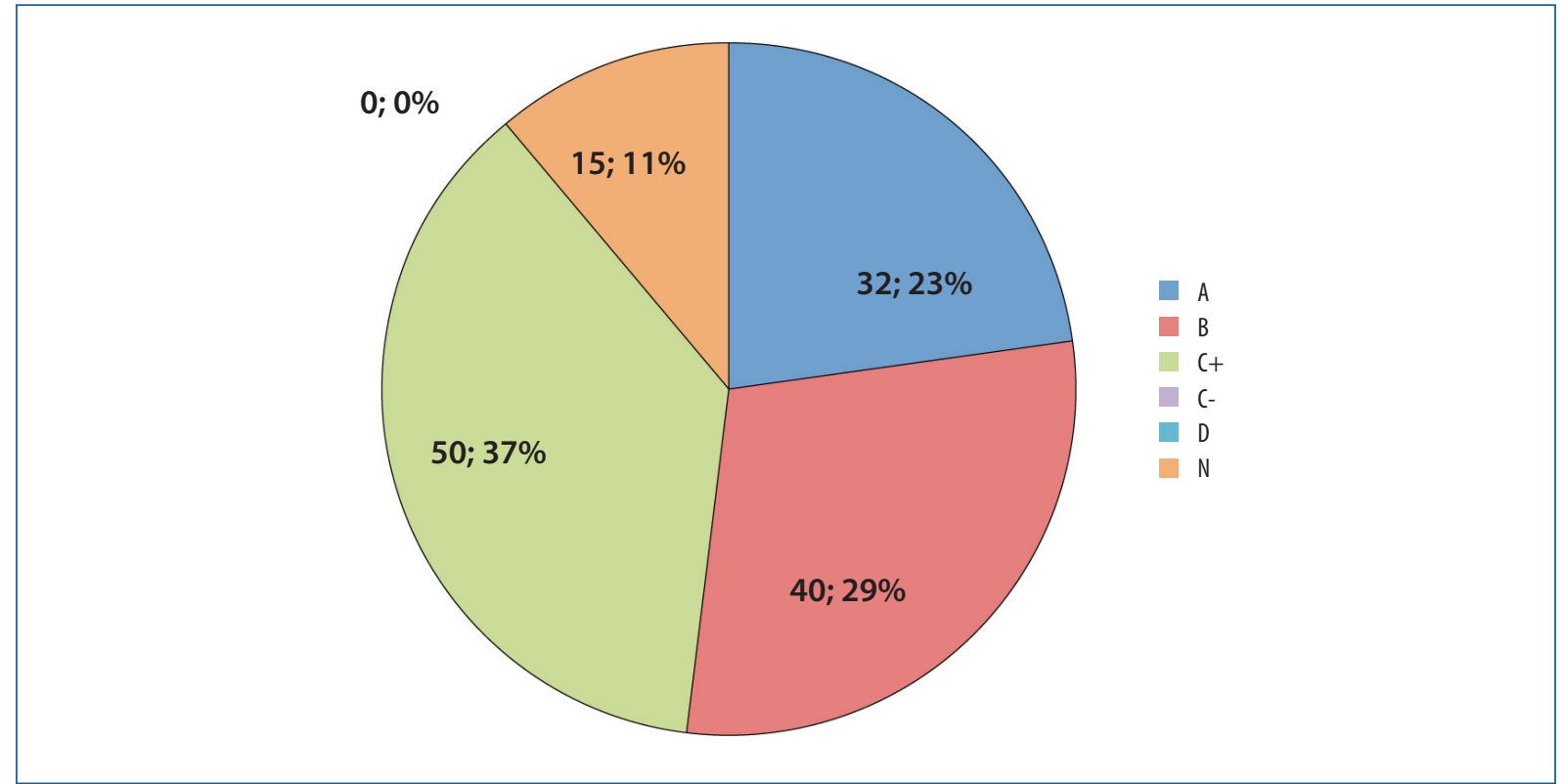

and tools, and the competency relating to the ability to manage consistently and sustainably (50 students in each case).

Chart 6. Grades awarded to the students for the competencies ${ }^{9}$

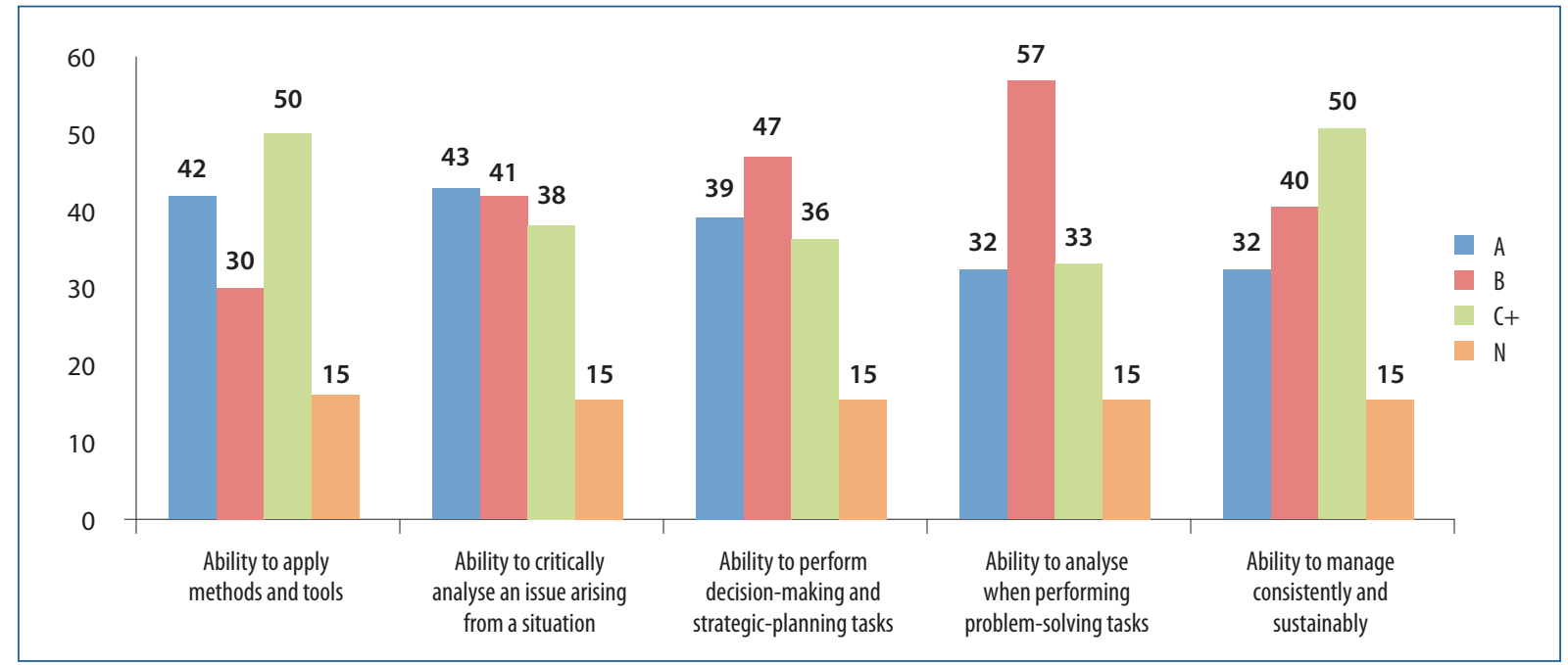

Fuente: elaboración propia a partir de los datos de las calificaciones de los estudiantes.

9. In these charts, grades $C$ - and D are not contemplated because it was understood that learning in this subject took place through active participation, and that throughout the learning process the students gradually acquired these competencies. Students that did not take the course or demonstrate the right level of knowledge, or who dropped out, were given an $\mathrm{N}$ grade. 
This chart also shows that the highest number of students got a grade B for competencies relating to decisionmaking and to the ability to analyse when performing problem-solving tasks, whereas the majority of the students got a grade A for the competency relating to the ability to critically analyse an issue arising from a situation.

The exploited data show that all the students worked on and successfully acquired the competencies via the SIMULACRE model. We can therefore confirm that this model effectively developed all five of the competencies analysed.

We also found that the students acquired some competencies better than others. According to the data obtained, we can confirm that the competencies that this model helped to develop the most were: the ability to perform problem-solving tasks (65\% of the students got good grades); followed by the competency relating to decision-making (63\% of the students got good grades); and the competency relating to critical analysis (61\% of the students got good grades). It is also important to highlight the fact that the highest number of students (43) got a grade $A$ for the latter of those three competencies.

\section{Final reflections}

As set out at the beginning of this article, the main issues that the SIMULACRE model aims to address with regard to the institutional practical training formerly offered at the UOC can be summarised as follows: (1) to overcome the requirement for students to be physically present, (2) the scant relationship between the students and the institutions' professionals, and (3) to bring practical training closer to the relevant aspects of an institution's management and day-to-day work. As the article has shown, a completely virtual alternative to face-to-face practical training has been designed. Based on a methodology combining video-format educational resources and simulation-game learning, problem-solving and collaborative learning, it is a new type of practical training that students who cannot be physically present are able to do. At the same time, it offers students the opportunity to interact with working professionals at the institutions on which their virtual practical training focuses. It is, therefore, a completely virtual, asynchronous type of practical training that fosters interaction between the students and institutions' professionals through exercises done in seminars. These exercises focus on those institutions' management aspects/issues. It is a model that offers students taking courses in e-learning mode the opportunity to do professional practical training that would otherwise be impossible; it enables them to do so actively by taking part in decision-making and in the institutions' day-to-day management.

In addition, the analysis of the results obtained following SIMULACRE's application shows that the students acquired a series of competencies that are crucial to their future professional practice, such as the ability to perform problem-solving tasks, the ability to perform decision-making tasks, the ability to critically analyse an issue arising from a situation, the ability to apply management methods and tools, and the ability to manage consistently and sustainably.

However, despite the good results obtained, it is important to point out that we identified certain limitations after the first application, referring to both collaboration with the institutions and its implementation, and to the acquisition of certain competencies. Regarding collaboration with the institutions, we have already highlighted that they collaborated selflessly in both the design and production of the resources, and participated in the seminars, but it is necessary to question whether this collaboration and the investment made in the audiovisual resources can be sustained over several semesters. It is also necessary to highlight the complexity of selecting the cases and,

RUSC VOL. 11 No 3 | Universitat Oberta de Catalunya and University of New England | Barcelona, July 2014

@ Alba Colombo and Muriel Gómez Pradas | @ 2014 by FUOC | SIMULACRE: A proposal for practical training in e learning environments 
in turn, the experts, especially as the latter need to be good instructors and discussion participants. Regarding the application of the model, certain limitations were also identified, such as the difficulties involved in implementing it with very large groups of students; the model was found to work with small groups, but its application and viability turned out to be complex with groups formed by high numbers of students.

We can conclude that SIMULACRE offers students the opportunity to gain access to and do practical training similar to face-to-face training, yet in a virtual, asynchronous way thanks to intensive educational design and monitoring. It is an e-learning methodology that offers students the opportunity to put their abilities, competencies and knowledge into practice in a real situation of an existing institution. However, in future applications, it will be necessary to address some issues, such as improving the development of certain competencies, and to take into account some of the comments made by the students participating in the first edition of the model's application, such as their investment of time and effort, the number of students per seminar and their desire to have even more contact with the professionals. One final point that must not be overlooked is that the sustainability of the collaborations with the institutions will need to be assured. Several new lines of research are opened up by this study, such as comparing the various editions of this model and, very especially, improving it, through either new types of resources, the application of 2.0 technologies, the inclusion of social networks to make it even more participatory, or the creation of new video resources by the students themselves. Such improvements will ensure that SIMULACRE remains an outstanding model for doing practical training in e-learning environments.

\section{References}

Beloki, N., Ordeñana, M. B., Darreche, L., González, M. N., Flecha, A. C., Hernando, M. C., Alonso, A., Mosquera, Á., \& Sanz, Z. (2011). Innovando el Practicum de Educación Social: una experiencia de trabajo colaborativo. Revista de Educación, 354, 237-264.

Busquets, A., \& Gómez, M. (2011). Instructional design and quality: learning strategies for the course plan and formative activities. A practical case of the Program of East Asian Studies. International Journal of Knowledge Society Research, 2(4), 44-58. doi http://dx.doi.org/10.4018/jksr.2011100104

Carnoy, M., Jarillo, B., Castano-Munoz, J., Duart, J. M., \& Sancho-Vinuesa, T. (2012). Who attends and completes virtual universities: the case of the Open University of Catalonia (UOC). Higher Education, 62, 53-82. doi http://dx.doi. org/10.1007/s10734-011-9424-0

Duart, J. M., \& Sangrà, A. (2000). Formación universitaria por medio de la web: un modelo integrador para el aprendizaje superior. In Aprender en la virtualidad (pp. 23-50). Barcelona: Gedisa.

Escribano, A., \&Valle, Á. (2010). El aprendizaje basado en problemas: una propuesta metodológica en educación superior. Madrid: Narcea Ed.

Ferreira De Araújo, U., \& Sastre, G. (coords.) (2008). El aprendizaje basado en problemas: una nueva perspectiva de la enseñanza en la universidad. Barcelona: Editorial Gedisa, S.A.

Fraile, E. (1995). La simulación y los modelos educativos en la enseñanza: una aproximación a los juegos de empresa abiertos. Bilbao: Universidad de Deusto, Departamento de Publicaciones.

Guitert, M., Lloret, T., Gimenez, F., \& Romero, T. (2005). El treball i l'aprenentatge cooperatius en entorns virtuals: el cas de la Universitat Oberta de Catalunya. Coneixement i Societat. Revista d'Universitats, Recerca i Societat de la Informacio, 8, 44-77.

RUSC VOL. 11 No 3 | Universitat Oberta de Catalunya and University of New England | Barcelona, July 2014 @a Alba Colombo and Muriel Gómez Pradas | @ 2014 by FUOC | SIMULACRE: A proposal for practical training in e learning environments 
López, E., \& Martínez, J. S. (2001). Iniciación a la simulación dinámica: aplicaciones a sistemas económicos yempresariales. Barcelona: Ariel.

Martín, E. (1985). Los juegos de simulación en EGB y BUP. Madrid: Universidad Autónoma de Madrid, Servicio de Publicaciones.

Molina, E., Iranzo, P., Lopez, M. C., \& Molina, M. Á. (2008). Procedimientos de análisis, evaluación y mejora de la formación práctica. Revista de Educación, 346, 335-361.

Monereo, C., \& Duran, D. (2003). Entramados: métodos de aprendizaje cooperativo y colaborativo. Barcelona: Edebé.

Nardone, G. (2010). Problem Solving Estratégico. Barcelona: Herder Editorial.

Pujolàs, P. (2007). Aprendre junts alumnes diferents. Vic: Eumo Editorial.

Santacana, T. (2006). El model pedagògic de la Universitat Oberta de Catalunya (UOC): una visió des de I'aula. Coneixement i Societat. Revista d'Universitats, Recerca i Societat de la Informacio, 10, 44-77.

Shaw, R.-S. (2012). A study of the relationships among learning styles, participation types, and performance in programming language learning supported by online forums. Computer \& Education, 58, 111-120. doi http:// dx.doi.org/10.1016/j.compedu.2011.08.013

Zabalza, M. A. (2011). El Prácticum en la formación universitaria: estado de la cuestión. Revista de Educación, 354, $21-43$.

\begin{abstract}
About the Authors
Alba Colombo

acolombo@uoc.edu

Lecturer in Arts and Humanities Studies, Universitat Oberta de Catalunya (UOC), Spain

Alba Colombo holds a doctorate (University of Girona, $U d G$ ), a bachelor's degree in History of Art (Autonomous University of Barcelona, UAB), a postgraduate qualification in Management and Administration of Cultural Institutions, Firms and Platforms (Pompeu Fabra University, UPF) and a master's degree in Information and Knowledge Society (Universitat Oberta de Catalunya, UOC). She is a lecturer in Arts and Humanities Studies at the UOC and collaborates with other universities as a lecturer on master's and postgraduate programmes. She is a collaborating member of the European Festival Research Project and has taken part in the development of the Arts Festivals and the European Public Culture Euro-Festivals project. She is a member of the Management and Administration of Social and Cultural Policies research group at the UdG. She has a long career in the field of national and international cultural management, and has collaborated with the Berlin International Film Festival, the European Film Academy, the Instituto Cervantes, the Government of Catalonia and the British Council, among others. She was en editorial member of several art criticism websites and is a collaborator on various journals and websites specialising in culture. She is the co-director of the Acción CULTURA collection published by EdiUOC and a panellist for the Ramon Roca Boncompte International Award for Cultural Management organised by Ros Roca and FiraTàrrega.
\end{abstract}




\section{Muriel Gómez Pradas}

mgomezpr@uoc.edu

Senior Lecturer in Arts and Humanities Studies, Universitat Oberta de Catalunya (UOC), Spain

Muriel Gómez Pradas holds a doctorate in History of Art (University of Zaragoza), a bachelor's degree in Geography and History, specialising in History of Art (University of Barcelona, UB), and a postgraduate qualification in Museography, Design and Conditionalities (Universitat Politècnica de Catalunya-BarcelonaTech, UPC). She was the curator at the Ethnological Museum of Barcelona and is a senior lecturer in Arts and Humanities Studies at the Universitat Oberta de Catalunya (UOC). She also collaborates with other universities as a lecturer. She was a Japan Foundation Fellowship Researcher at the National Museum of Japanese History (Sakura-shi, Chiba-ken) and Sagano Ningyo no le (Kyoto). She is a member of the Japan and Spain: Relations through Art research group that has been awarded funding for three R\&D projects by the Spanish Ministry of Education and Science to study Japanese collections in the State. She has an extensive career linked to the sphere of museums and the management of their collections, research and teaching. She is the author of various publications, books, articles and papers for national and international conferences, focusing on museum collections, traditional Japanese art and e-learning, as well as educational resources for university subjects.

Universitat Oberta de Catalunya

Av. Tibidabo 39-43

08035 Barcelona

Spain

Original title SIMULACRE: Una propuesta de prácticas en entornos e-learning

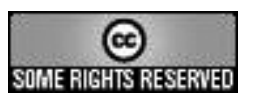

The texts published in this journal are - unless indicated otherwise - covered by the Creative Commons Spain Attribution 3.0 licence. You may copy, distribute, transmit and adapt the work, provided you attribute it (authorship, journal name, publisher) in the manner specified by the author(s) or licensor(s). The full text of the licence can be consulted here: <http://creativecommons.org/licenses/by/3.o/es/deed.en>

\section{$\bullet$ UOC \\ Universitat Oberta

